\title{
MOTYWY PODEJMOWANIA AKTYWNOŚCI FIZYCZNEJ W CZASIE WOLNYM PRZEZ STUDENTÓW TRENUJĄCYCH I NIETRENUJĄCYCH
}

\section{MOTIVATIONS FOR PHYSICAL ACTIVITY IN ATHLETES AND NON-ATHLETES}

\author{
Ewa Stępieńn ${ }^{1(B, C, D, E, F)}$, Jacek Stępieńn ${ }^{2(B, C, D, E, F)}$, Maciej Olesiejuk ${ }^{2(A, B, C, D, E)}$ \\ ${ }^{1}$ Wydział Nauk o Zdrowiu i Nauk Społecznych, \\ Państwowa Szkoła Wyższa im. Papieża Jana Pawła II w Białej Podlaskiej \\ ${ }^{2}$ Wydział Turystyki i Zdrowia, Akademia Wychowania Fizycznego Józefa Piłsudskiego w Warszawie, \\ Filia w Białej Podlaskiej
}

\begin{abstract}
Stępień, E., Stępień, J., Olesiejuk, M. (2019). Motywy podejmowania aktywności fizycznej w czasie wolnym przez studentów trenujących i nietrenujących. Rozprawy Społeczne, 13(1), 64-71. https://doi.org/10.29316/rs.2019.08
\end{abstract}

Wkład autorów:

A. Zaplanowanie badań

B. Zebranie danych

C. Dane - analiza i statystyki

D. Interpretacja danych

E. Przygotowanie artykułu

F. Wyszukiwanie i analiza

literatury

G. Zebranie funduszy

Tabele: 0

Ryciny: 7

Literatura: 28

Otrzymano: styczeń 2018

Zaakceptowano: kwiecień 2018

\begin{abstract}
Streszczenie
Wstęp. Celem naszych badań była analiza porównawcza dotycząca aktywności fizycznej w czasie wolnym i motywów jej podejmowania przez studentów trenujących i nietrenujących.

Materiał i metody. Badaniami objęto studentów dwóch bialskich uczelni - Państwowej Szkoły Wyższej im. Papieża Jana Pawła II w Białej Podlaskiej i Akademii Wychowania Fizycznego Józefa Piłsudskiego w Warszawie, Filii w Białej Podlaskiej. Ogółem przebadano 130 osób: 65 sportowców i 65 nieuprawiających sportu wyczynowo.

Wyniki. Na podstawie analizy wyników badań można wywnioskować, iż wyczynowe uprawianie sportu różnicuje opinie badanych dotyczące spędzania czasu wolnego oraz ich uczestnictwo w zajęciach sportowo-rekreacyjnych.

Wnioski. Studenci uprawiający sport wyczynowo większą uwage przywiazuja do rekreacji ruchowej i są dwukrotnie bardziej aktywni fizycznie w czasie wolnym od studentów, którzy sportu nie uprawiaja. Motywami różnicujacymi podejmowanie aktywności fizycznej przez badanych są: kształtowanie charakteru, zdobycie nowych umiejętności, względy towarzyskie, kariera sportowa oraz poprawa zdrowia - wymienia większość sportowców. Studenci uprawiający sport wyczynowo dostrzegają znacznie więcej korzyści zdrowotnych, jakie daje regularna aktywność fizyczna.
\end{abstract}

Słowa kluczowe: aktywność fizyczna, motywy, studenci.

\section{Summary}

Introduction. The purpose of our research was a comparative analysis of physical activity in free time and the motives of its performance in students doing sports professionally and those who do not.

Material and methods. The study involved students from two Polish higher education institutions - Pope John Paul II State School of Higher Education in Biała Podlaska and Józef Piłsudski University of Physical Education in Warsaw, Faculty of Physical Education and Sport in Biała Podlaska. In total, 130 people were tested: 65 athletes and 65 non-professional athletes. Results. On the basis of the analysis of the results of the research, it can be concluded that being involved in performing sport professionally affects respondents' opinions concerning leisure time and their participation in sports and leisure activities.

Conclusions. Students who do sports are more attentive to physical recreation and are twice as physically active during leisure time than those who do not practice sports. The motives which affect the respondents' physical activity include character formation, acquisition of new skills, social skills, sports career and health improvement. Professional athletes understand the health benefits of regular physical activity.

Keywords: physical activity, motives, students 


\section{Wstęp}

Aktywność fizyczna jest powszechnym miernikiem zdrowia we wszystkich okresach życia człowieka. W licznych publikacjach autorzy uważają, że w warunkach współczesnej cywilizacji największym niebezpieczeństwem zagrażającym zdrowiu jest sedenteryjny tryb życia (Drygas, 2006, Kantoma, Tammelin, Taanola, 2008, Czaplicki, 2008). Stanowi ona przedmiot wielu badań naukowych w Polsce i na świecie (Bauman i in. 2009, Biernat, 2011, Soguksu, 2011, Kaźmierczak i in. 2015, Mynarski, Rozpara, Królikowska, Puciato, Graczykowska, 2012, Bergier B., Stepień, Niźnikowska, Bergier J., 2014, Wojciechowski, Bergier J., 2016) a najczęściej poruszany jest $\mathrm{w}$ nich problem społecznej i zdrowotnej wartości ruchu, poziomu aktywności fizycznej, uwarunkowań i motywów jej podejmowania (Czaplicki, 2008, Markiewcz-Górka, Korneluk, Pirogowicz, 2011, MSiT 2015).

Organizacje światowe, takie jak WHO (World Health Organization), FIMS (Federation Internationale de Medecine Sportive), CDDS (Committee for the Development of Sport) zaniepokojone narastającą hipokinezją wezwały kraje do prozdrowotnej promocji aktywności fizycznej, jako zasadniczego celu nowoczesnej strategii zdrowia publicznego (Biernat 2011).

Wiele badań dotyczących aktywności fizycznej różnych grup społecznych poświęca się grupie studentów Wang, Byrne, Kenardy, Hills (2005), Currie i in. (2012), Klarin, Pororoković, Sacic, Arnaudova (2012), Rothon, Goodwin (2012), Novak, Doubova, Kawachi (2016). Badania polskiej młodzieży akademickiej prowadzili m.in. Sokołowski, Bronowicki, Kaiser (2008), Kijo (2010), Biernat, (2011), Baj-Korpak i in. (2014), Stępień, Bergier B., Niźnikowska, Bergier J., (2015). Odczuwany jest jednak brak badań na temat motywów podejmowania aktywności fizycznej w czasie wolnym studentów profesjonalnie zajmujących się sportem oraz ich opinii na temat zdrowotnej roli oraz zagrożeń wynikających $\mathrm{z}$ uprawiania sportu.

\section{Materiał i metody}

Badaniami objęto studentów dwóch bialskich uczelni - Państwowej Szkoły Wyższej im. Papieża Jana Pawła II i Akademii Wychowania Fizycznego Józefa Piłsudskiego w Warszawie, Filii w Białej Podlaskiej. Ogółem 130 osób: 65 trenujących i 65 nietrenujących studentów. Po selekcji materiału do obróbki statystycznej zakwalifikowano 112 kwestionariuszy (w tym 59 uzyskanych od studentów trenujących z Akademii Wychowania Fizycznego Józefa Piłsudskiego w Warszawie, Filii w Białej Podlaskiej i 53 nietrenujących z PSW). Doboru próby dokonano w sposób celowy, tak aby grupę sportowców reprezentowali przedstawiciele różnych dyscyplin: koszykówki, pływania, podnoszenia ciężarów, piłki nożnej i tańca. Do grupy niespor- towców wybrano studentów takich kierunków jak turystyka i rekreacja, budownictwo, fizjoterapia i pielęgniarstwo.

Badaniem objęto 112 osób, w tym 45 kobiet i 67 mężczyzn.

Respondentami były osoby w wieku od 19 do 29 lat. Około $61 \%$ badanych miało nie więcej niż 21 lat, średnia wieku wynosiła 21,6 lat. Współczynnik zmienności na poziomie $11,6 \%$ świadczy o małym zróżnicowaniu wieku badanej grupy. Srodkowe $50 \%$ badanych studentów było w wieku od 20 do 23 lat.

Spośród badanych 53\% stanowili studenci Państwowej Szkoły Wyższej oraz 47\% Akademii Wychowania Fizycznego Józefa Piłsudskiego w Warszawie, Filii w Białej Podlaskiej. W grupie wszystkich respondentów 53\% to studenci uprawiający sport wyczynowo. Najliczniejszą grupę badanych stanowiły osoby trenujące pływanie - Akademia Wychowania Fizycznego Józefa Piłsudskiego w Warszawie, Filia w Białej Podlaskiej (38\%) oraz studenci reprezentujący kierunki medyczne, takie jak: fizjoterapia i pielęgniarstwo - PSW (39\%).

W badaniach zastosowano metodę sondażu diagnostycznego. Materiał sondażowy pozyskano przy pomocy autorskiej ankiety, której kwestionariusz zweryfikowano w badaniach pilotażowych na grupie 20 studentów (10 trenujących i 10 nietrenujących).

Do pomiaru uzyskanych od respondentów danych wykorzystano skalę Likerta. Skala składa się z kafeterii liczącej pięć odpowiedzi dotyczących przedmiotu badań, ułożonych w porządku od stopnia absolutnej akceptacji do całkowitej negacji (odrzucenia). Każdemu twierdzeniu towarzyszy osobna skala indywidualna, na której respondenci mogą wyrazić, w jakim stopniu zgadzają się lub nie zgadzają się z treścią przedstawionego twierdzenia. Wszystkie twierdzenia mają identyczną pięciostopniową skalę odpowiedzi od +2 do -2 . Oceny skrajne -2 = zdecydowanie nie (albo nigdy), oraz +2 = zdecydowanie tak (albo zawsze, bardzo często). Respondenci oceniają czy konkretne zdanie jest zgodne $\mathrm{z}$ ich przekonaniami.

Wyniki badań empirycznych poddano analizie statystycznej przy użyciu programów Excel i Statistica 10. Opinie respondentów zbadano wykorzystując pięciostopniową skalę Likerta. Przeprowadzając analizę otrzymanych wyników obliczono podstawowe parametry dotyczące rozkładu normalnego: średnią arytmetyczną i odchylenie standardowe. Poszukiwanie zależności między cechami uwarunkowane jest poziomem dokonanego pomiaru. W celu wykrycia wpływu wyczynowego uprawiania sportu na wyodrębnione zmienne wykorzystano test t-Studenta dla prób niezależnych. W przypadku cech mierzonych na skali nominalnej wnioskowanie statystyczne przeprowadzono za pomocą testu niezależności Chi-kwadrat Pearsona. W obliczeniach przyjęto poziom istotności wynoszący $\mathrm{p}<0,05$. 


\section{Wyniki badań}

Na podstawie analizy wyników stwierdzono, że większość respondentów poświęca czas wolny na słuchanie muzyki, odpoczynek i relaks (średnia 1,38), oglądanie telewizji, korzystanie z Internetu (średnia 0,88 ) oraz na zajęcia sportowo-rekreacyjne (średnia 0,87 ). Na podstawie wyników można uznać, iż aktywność fizyczna jest jedną z ulubionych przez studentów form wykorzystania wolnego czasu. Wyczynowe uprawianie sportu różnicuje opinie badanych dotyczące spędzania czasu wolnego oraz ich uczestnictwo w zajęciach sportowo- rekreacyjnych $(t=3,24 ; d f=110 ; p=0,0016)$. Sportowcy większą uwagę przywiązują do rekreacji ruchowej i są dwukrotnie bardziej aktywni fizycznie w czasie wolnym od studentów, którzy sportu nie uprawiają (rycina 1).
W celu pogłębienia wiedzy dotyczącej aktywności fizycznej badanych w czasie wolnym, analizie poddano formy oraz częstotliwość podejmowania przez nich rekreacji ruchowej.

Do form ruchu, które badani studenci podejmują najczęściej w czasie wolnym należą gry zespołowe (średnia 0,98 ) oraz pływanie (średnia 0,80 ). Najrzadziej zaś grają w tenisa i jeżdżą konno. Ćwiczenia w siłowni $(t=4,35 ; d f=110 ; p=0,0000)$ są formą ruchu, która znaczaco różnicuje badane grupy. Studenci trenujący zdecydowanie chętniej podejmują ćwiczenia siłowe (średnia 1,02), niż studenci nietrenujący (średnia 0,02) (rycina 2). Inaczej jednak kształtuje się sytuacja w przypadku marszów i biegów $(\mathrm{t}=-2,25 ; \mathrm{df}=110 ; \mathrm{p}=0,0264)$. Studenci wyczynowo uprawiający sport rzadziej (średnia 0,27) w porównaniu z nietrenującymi (średnia 0,77 ) podejmują tę formę ruchu w czasie wolnym (rycina 2).

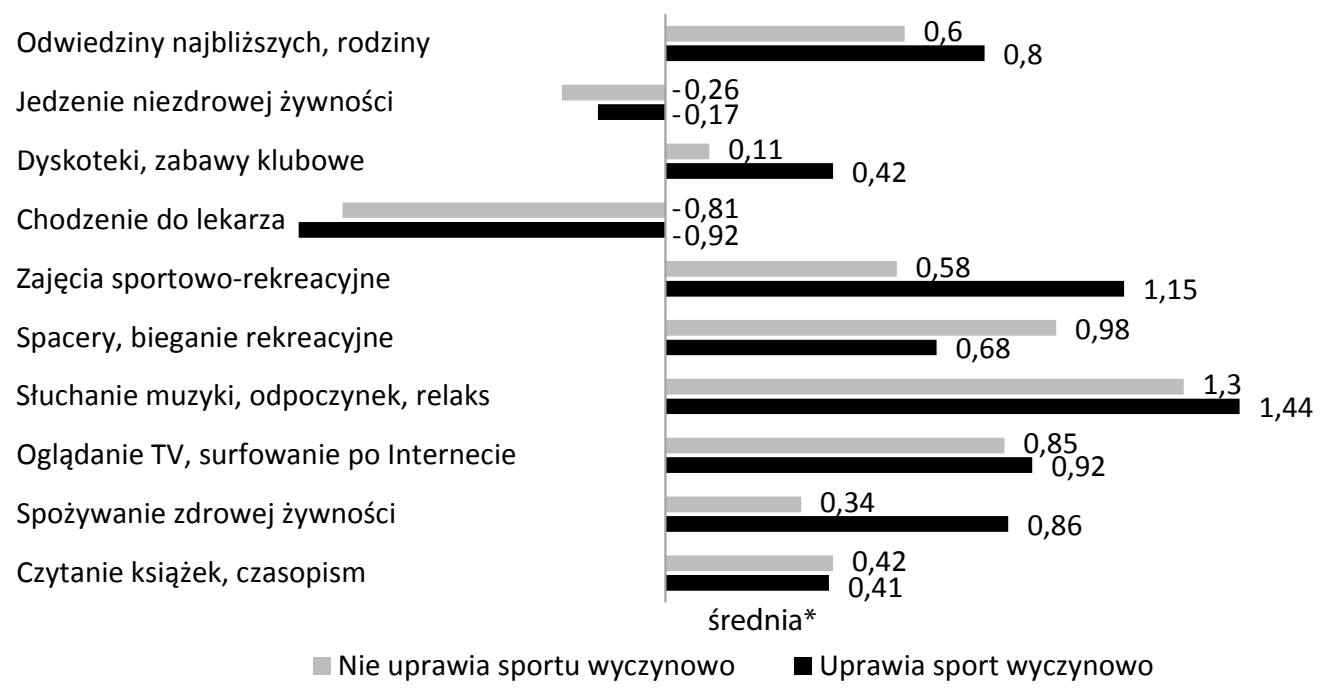

Rycina 1. Rodzaje wykorzystania czasu wolnego przez respondentów uprawiających i nieuprawiających sportu wyczynowo (* skala: 2 - bardzo lubię, -2 - zdecydowanie nie lubię)

Źródło: Opracowanie własne

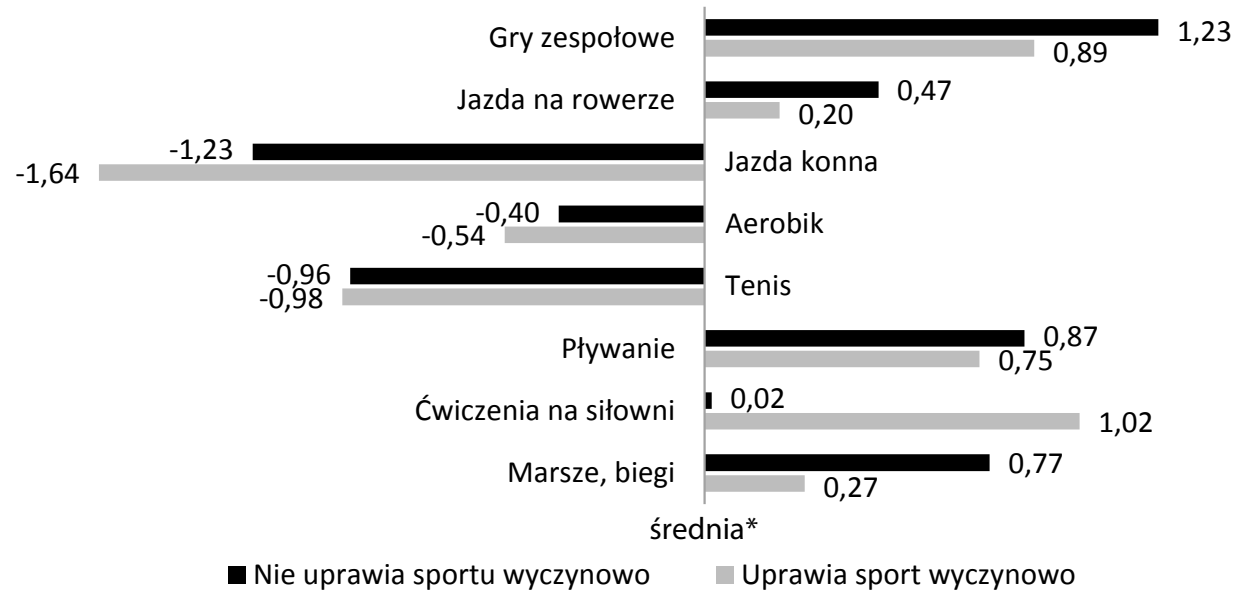

Rycina 2. Formy ruchu podejmowane w czasie wolnym przez respondentów uprawiających sport i niesportowców (* skala: 2 - bardzo często, -2 - nie podejmuje)

Źródło: Opracowanie własne 
Ponad 75\% wyczynowych sportowców podejmuje rekreacyjną aktywność fizyczną codziennie lub 4-5 razy w tygodniu. Natomiast ponad 70\% osób nieuprawiających sportu stosuje ulubione formy ruchu rzadziej niż 4 razy w tygodniu. Sportowcy również więcej czasu w ciągu tygodnia poświęcają na aktywność fizyczną (rycina 3).

Ważne $\mathrm{z}$ punktu widzenia realizacji celu badań było uzyskanie informacji na temat motywów podejmowania rekreacyjnej aktywności fizycznej przez respondentów. Z analizy danych wynika, że do motywów najczęściej deklarowanych przez ankietowanych należą: możliwość wyżycia się, rozładowania stresu, względy estetyczne i utrzymanie prawidłowej masy ciała. Wyniki wskazują również, że wysokie oceny uzyskały motywy, które jednocześnie różnicują opinie badanych. Sportowców w większym stopniu, niż niesportowców motywuje do regularnej aktywności fizycznej (średnia powyżej 1,0): kształtowanie charakteru $(\mathrm{t}=2,75$; $\mathrm{df}=110 ; \mathrm{p}=0,0070)$, zdobycie nowych umiejętności $(\mathrm{t}=2,85 ; \mathrm{df}=110 ; \mathrm{p}=0,0052)$, względy towarzyskie $(t=3,55 ; d f=110 ; p=0,0006)$, kariera sportowa $(\mathrm{t}=5,18 ; \mathrm{df}=110 ; \mathrm{p}=0,0000)$, oraz zachowanie zdrowia, relaks i rozładowanie stresu (rycina 4).

Ankietowani obu badanych grup podkreślali pozytywny wpływ aktywności fizycznej na zdrowie oraz skuteczne pełnienie ról życiowych. Opinie studentów profesjonalnie zajmujących się sportem (średnia 0,61) i niesportowców (średnia 0,75) na temat wpływu aktywności fizycznej na skuteczne pełnienie ról społecznych, zawodowych i rodzinnych, nie różnią się istotnie $(\mathrm{t}=-0,78 ; \mathrm{df}=110$; $p=0,4379$ ) (rycina 5).

Jednakże na podstawie analizy wyników badań można przypuszczać, że sportowcy dostrzegają więcej korzyści zdrowotnych, jakie daje podejmowanie aktywności fizycznej w życiu codziennym.

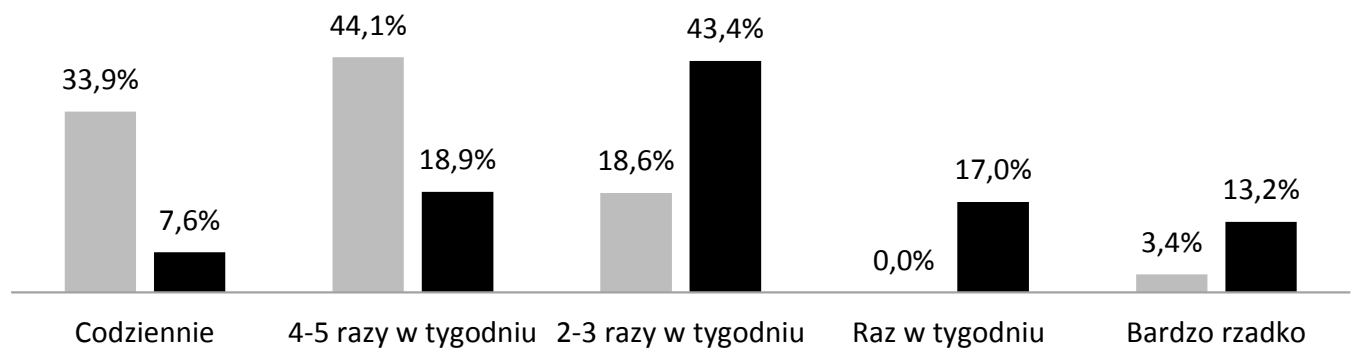

Uprawia sport wyczynowo $\quad$ Nie uprawia sportu wyczynowo

Rycina 3. Częstotliwość podejmowania rekreacyjnej aktywności fizycznej w ciągu tygodnia przez sportowców i niesportowców (\% odpowiedzi respondentów)

Źródło: Opracowanie własne

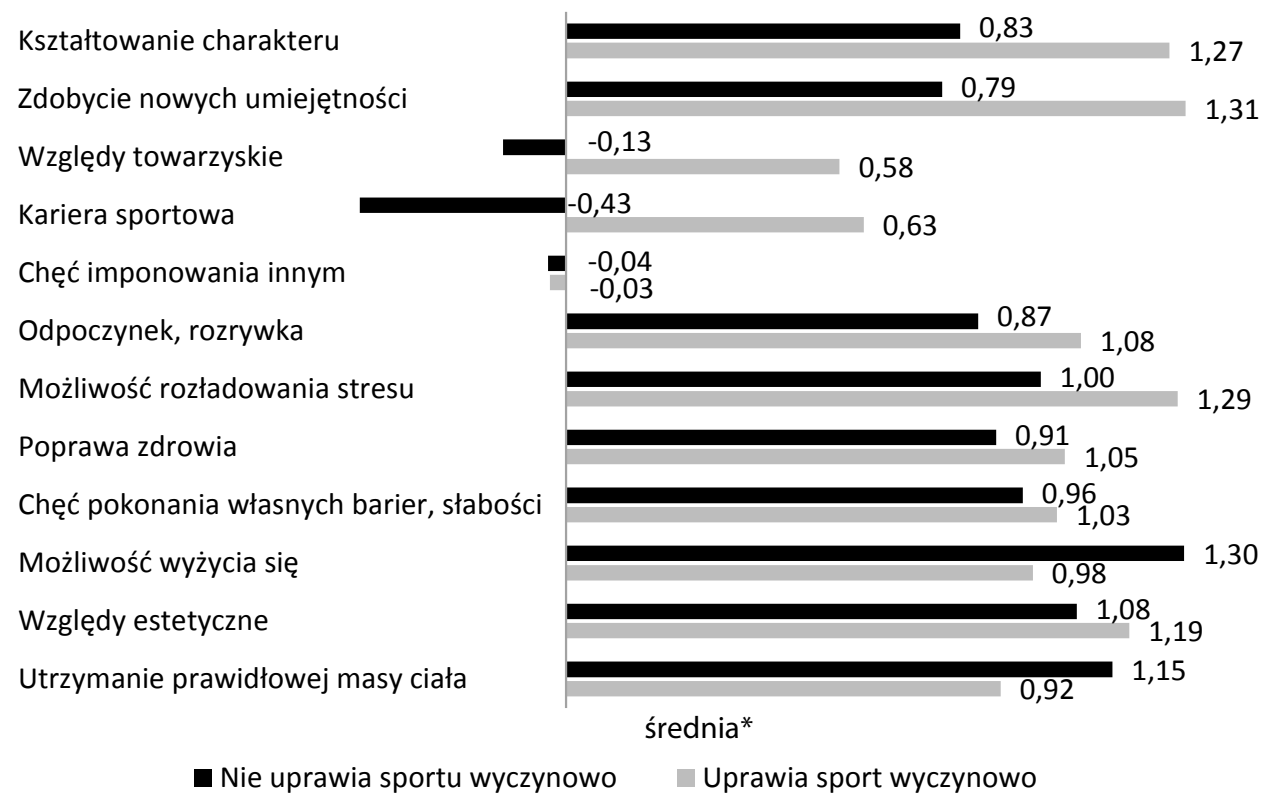

Rycina 4. Motywy podejmowania aktywności fizycznej przez studentów uprawiających sport i niesportowców (*skala: 2 zdecydowanie tak, -2 - zdecydowanie nie)

Źródło: Opracowanie własne 


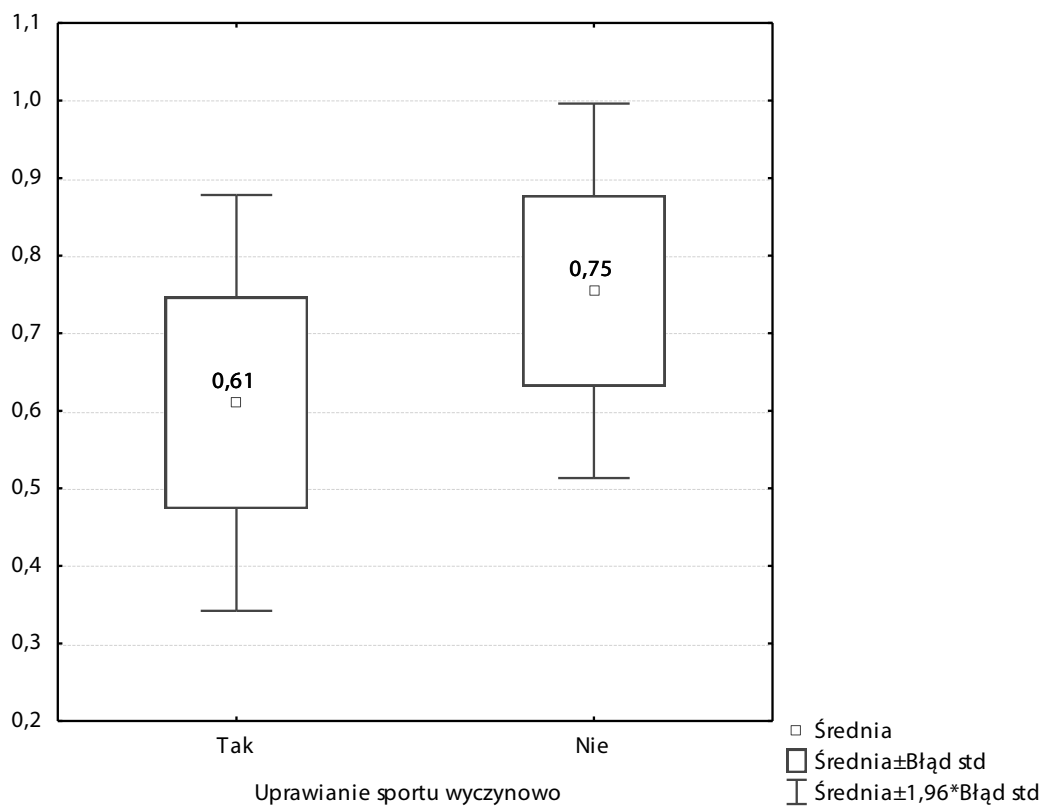

Rycina 5. Ocena wpływu aktywności fizycznej na pełnienie ról społecznych, zawodowych i rodzinnych w opinii studentów sportowców i nieuprawiających sportu wyczynowo (*skala: 2 -tak, bardzo; -2 - zdecydowanie nie)

Źródło: Opracowanie własne

W badaniach poddano także analizie opinie respondentów dotyczące korzyści i zagrożeń wynikających z wyczynowego uprawiania sportu. Z analizy można wnioskować, że studenci za najważniejsze korzyści, wynikające z uprawiania sportu, uznają: wysoką sprawność i wydolność organizmu (średnia 1,56), oraz dbanie o siebie i właściwą masę ciała (średnia 1,46). Na podstawie badań nie można stwierdzić, by uprawianie sportu wpływało w istotny sposób na dobre relacje rodzinne, koleżeńskie (średnia 0,52), czy też uznanie w środowisku, bądź wyeliminowanie używek (średnia poniżej $0,8)$ (Rycina 6).

Wyczynowe uprawianie sportu różnicuje opinie badanych w odniesieniu do takich czynników, jak kształtowanie nawyków higienicznych $(\mathrm{t}=3,63$; $\mathrm{df}=110 ; \mathrm{p}=0,0004)$. Studenci uprawiający sport wyczynowo uznali, w większym stopniu niż studen- ci niesportowcy że uprawianie sportu wpływa korzystnie na ten czynnik (sportowcy - średnia 1,31, niesportowcy - średnia 0,77). Sportowcy zauważają zdecydowanie mniej korzyści wynikających z uprawiania sportu (średnia 0,49) w stosunku do drugiego czynnika różnicującego obie grupy, jakim jest wyeliminowanie używek, tytoniu, alkoholu $(\mathrm{t}=-2,78 ; \mathrm{df}=110 ; \mathrm{p}=0,0064)$, przy czym niesportowcy uznali, iż sport działa na ten czynnik korzystnie (średnia 1,04). Opinie sportowców wykazały również istotny statystycznie większy wpływ uprawiania sportu (średnia 0,93 ) na uznanie i prestiż w środowisku ( $t=2,08 ; d f=110 ; p=0,0394)$.

Studenci nieuprawiający sportu bardziej krytycznie, niż sportowcy oceniają jego wpływ na zdrowie człowieka. W oparciu o wyniki stwierdzono dwa czynniki różnicujące $\mathrm{w}$ tej kwestii grupy badane. Niesportowcy bardziej krytycznie ocenili

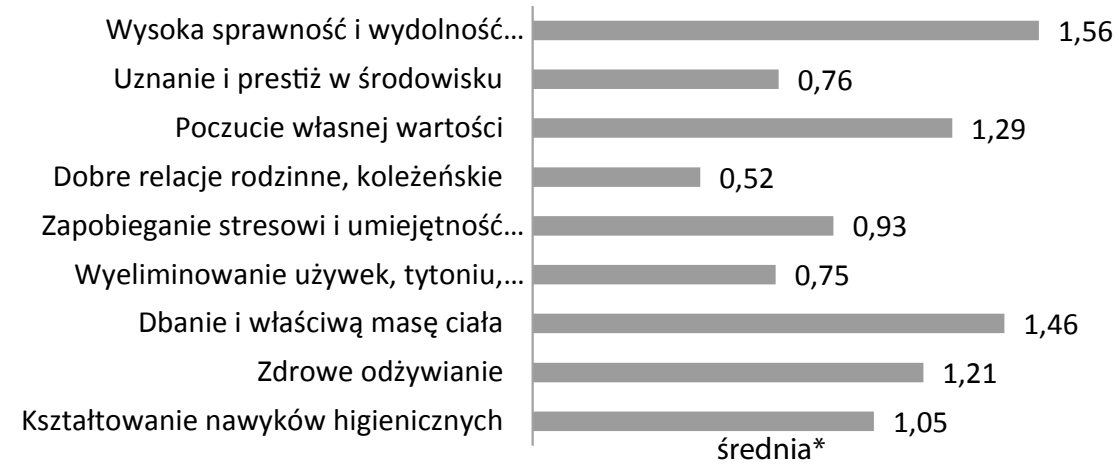

Rycina 6. Ocena wpływu uprawiania sportu na wybrane czynniki $\left({ }^{*}\right.$ skala: 2 - zdecydowanie tak, $-2-$ zdecydowanie nie) Źródło: Opracowanie własne 


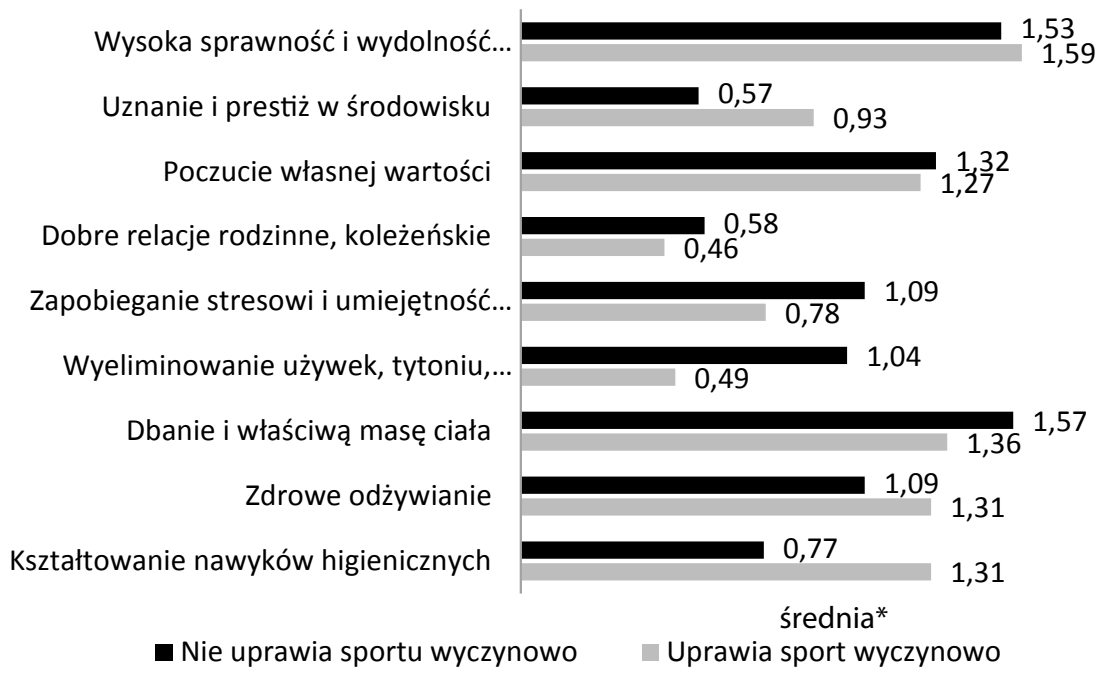

Rycina 7. Ocena wpływu uprawiania sportu na wybrane czynniki przez sportowców i niesportowców (* skala: 2 - zdecydowanie tak, -2 - zdecydowanie

Źródło: Opracowanie własne

wpływ uprawiania sportu na kształtowanie się nawyków higienicznych oraz uznanie i prestiż w środowisku (rycina 7). Pozostałe czynniki nie różnicują istotnie opinii respondentów obu grup.

\section{Dyskusja}

Aktywność fizyczna w czasie wolnym jest nieodzownym czynnikiem wpływającym na zdrowie, nastrój człowieka i stanowi ważny element zdrowego stylu życia. Według I. Kiełbasiewicz-Drozdowskiej (2001), aktywność fizyczna jest potrzebna człowiekowi na każdym etapie jego życia i w każdej grupie wieku. Aktywność fizyczna podejmowana była od początku istnienia ludzkości, jednakże motywy skłaniające do rekreacji ruchowej zmieniały się wraz ze zmieniającymi się warunkami i nowymi trendami społecznymi, środowiskowymi, politycznymi, ekonomicznymi i edukacyjnymi.

Wyniki naszych badań nie różnią się znacząco od wyników uzyskanych przez innych autorów. Wskazują one, że aktywność fizyczna sprawia studentom przyjemność, daje odprężenie psychiczne. Zarówno studenci profesjonalnie zajmujący się sportem jak też niesportowcy doceniają zdrowotną rolę aktywności fizycznej, nie zawsze jednak ma to odbicie w ich codziennym życiu (Zaleski, Niewęgłowski 2006, Łaszek, Nowacka, Gawron-Skarbek, Szatko 2011). Analizując badania Prusik, Zaporoshanov, Görner (2009) stwierdzono, że głównymi motywami podejmowania aktywności fizycznej przez studentów Akademii Wychowania Fizycznego i Sportu w Gdańsku jest przyjemność, zachowanie zdrowia i wysokiej kondycji fizycznej. Na podstawie analizy wyników badań Figaj i Poczty (2016) najważniejszymi motywami podejmowania aktywności fizycznej przez osoby trenujące Crossfit są: poprawa wytrzymałości, utrata tkanki tłuszczowej, popra- wa zdrowia, dobra zabawa, odreagowanie stresu. Kościuczuk, Krajewska-Kułak, Okurowska-Zawada (2016) prowadząc badania wśród studentów fizjoterapii i dietetyki stwierdziły, że formami aktywności fizycznej najczęściej wybieranymi przez badanych są: aerobik, gimnastyka, pływanie, taniec, zajęcia w siłowni, jazda rowerem i spacery. Motywami zaś: zachowanie dobrej formy fizycznej, odreagowanie stresu, utrzymanie idealnej sylwetki, redukcja masy ciała. Al. Sudani, Budzyńska, (2014) przebadały 300 kobiet w wieku 25-28 lat, które najchętniej uczestniczyły w zajęciach fitness, biegały i spacerowały a najważniejszymi motywami podejmowania tych aktywności były pasja, lepsze samopoczucie, zdrowie oraz spotkanie przyjaciół podczas ćwiczeń.

Analiza wyników badań prezentowanych na przestrzeni ostatnich kilku lat wskazuje, że motywy podejmowania aktywności fizycznej nie zmieniły się w sposób znaczący. Do najważniejszych należą: uzyskanie zgrabnej sylwetki, dbanie o zdrowie i kondycję fizyczną (Markiewcz-Górka i in. 2011, Klarin, Pororoković, Sacic, Arnaudova 2012, Al. Sudani, Budzyńska 2014).

Znaczenia nabierają wciąż działania edukacyjne zmierzające do upowszechniania zdrowego stylu życia, realizowane na wszystkich poziomach edukacji. Szczególna rola przypada w tym względzie wyższym uczelniom. Charakterystyczny uczelniany styl życia wpływa na kształtowanie osobowości studentów, systemu wartości i norm postępowania.

\section{Wnioski}

Ulubioną formą zajęć w czasie wolnym respondentów obu grup, jest słuchanie muzyki, oglądanie telewizji, korzystanie z Internetu oraz zajęcia sportowo - rekreacyjne. Należy jednak zaznaczyć, 
że studenci uprawiający sport wyczynowo są dwukrotnie bardziej aktywni fizycznie w czasie wolnym od osób nietrenujących.

Do form ruchu, które badani studenci podejmują najczęściej należą gry zespołowe i pływanie. Najrzadziej grają w tenisa i jeżdżą konno. Takie formy jak: ćwiczenia siłowe oraz marsze i biegi w sposób istotny różnicują respondentów. Sportowcy zdecydowanie częściej podejmują ćwiczenia siłowe i rzadziej niż niesportowcy biegają i maszerują.

Studenci uprawiający sport dostrzegają więcej korzyści z jego uprawiania niż niesportowcy. Podkreślają rolę sportu w kształtowaniu się nawyków higienicznych oraz wpływ na uznanie i prestiż w środowisku.

Do motywów podejmowania regularnie rekreacyjnej aktywności fizycznej przez respondentów obu grup należą: możliwość wyżycia się, rozładowanie stresów i utrzymanie prawidłowej masy cia- ła. Motywami różnicującymi badanych są: kształtowanie charakteru, zdobycie nowych umiejętności, względy towarzyskie, kariera sportowa oraz poprawa zdrowia.

Sportowcy dostrzegają znacznie więcej korzyści zdrowotnych, jakie daje regularna aktywność fizyczna. Natomiast opinie respondentów na temat wpływu tej aktywności na skuteczne pełnienie ról społecznych, zawodowych i rodzinnych nie różnią się istotnie.

Opinie respondentów dotyczące korzyści i zagrożeń wynikających z wyczynowego uprawiania sportu nie różnicują $\mathrm{w}$ istotny sposób ankietowanych. Badani obu grup podkreślają korzystny wpływ na podniesienie sprawności i wydolności organizmu. Nie dostrzegają istotnego wpływu uprawiania sportu na dobre relacje rodzinne, koleżeńskie czy wyeliminowanie używek.

\section{Literatura:}

1. Al. Sudani, A.A., Budzyńska, K. (2014). Aktywność fizyczna studentek- motywy podejmowania i zachowania antyzdrowotne, Wychowanie Fizyczne i Zdrowotne, 5, 10-13.

2. Baj-Korpak, J., Korpak, F., Sudoł G. (2014). Physical activity of students of University of Physical Education in Krakow and the Faculty of Physical Education and Sport in Biała Podlaska. Antropomotoryka, 66(24), 59-68. https://doi.org/10.5604/17310652.1149307

3. Bauman, A., Bull, F., Chey, T., et al. (2009). The IPS Group: The International Prevalence Study on Phisical Activity: results from 20 countries, Int. J. Behar. Nutr. Phys. Act., 6(1), 2. https://doi.org/10.1186/14795868-6-21

4. Bergier, B., Stępień, E., Niźnikowska, E., Bergier, J. (2014). Aktywność fizyczna kobiet i mężczyzn studiujących w Państwowej Szkole Wyższej w Białej Podlaskiej. Medycyna Ogólna i Nauki o Zdrowiu, 20 (2), 166-170. https://doi.org/10.5604/20834543.1112232

5. Biernat, E. (2011). Aktywność fizyczna mieszkańców Warszawy na przykładzie wybranych grup zawodowych. Warszawa: Oficyna Wydawnicza SGH.

6. Currie, C., Zanotti, C., Morgan, A., Currie, D., de Looze, M., Roberts, C. (2012). Social determinants of health and well-being among young people. Health behavior in school-aged children (HBSC) study: international report from the 2009/2010 survey (Health policy for children and adolescents No. 6). Copenhagen: WHO Regional Office for Europe, 129-132.

7. Czaplicki, Z. (2008). Aktywność ruchowa - atrybutem kultury zdrowotnej człowieka, Wychowanie Fizyczne i Zdrowotne, 4, 25 - 31.

8. Drygas, W. (2006). Czy siedzący tryb życia nadal stanowi zagrożenie dla zdrowia społeczeństwa polskiego? Medycyna Sportowa, 22(2), 111-116.

9. Figaj, D., Poczta, J. (2016). Motywy podejmowania aktywności fizycznej na przykładzie osób trenujących crossfit, Journal of Education, Health and Sport;6(6), 95-106.

10. Kantoma, M., Tammelin, T.H., Taanola, A.M. (2008). Emotional and Behavioral Problems In Relation to Physical Activity in Youth, Medicine and Science In Sports and Exercise, 40(10), 1749-1756. https://doi. org/10.1249/mss.0b013e31817b8e82

11. Kaźmierczak, U., Radzimińska, A., Dzierżanowski, M., Bułatowicz, I., Strojek, K., Srokowski G., i in. (2015). Korzyści z podejmowania regularnej aktywności fizycznej przez osoby starsze. Journal of Education, Health and Sport.; 5(1), 56-68.

12. Kiełbasiewicz - Drozdowska, I., Siwiński, W. (2001). Teoria i metodyka rekreacji (zagadnienia podstawowe). Poznań: AWF.

13. Kijo, P. (2010). Aktywność fizyczna wśród studentów kierunków pedagogicznych łódzkich uczelni publicznych i niepublicznych, W: Z. Barabasz, E. Zadarko (red.), Aktywność przez całe życie. Zdrowie i sprawność studentów pod kontrolq (s. 157-180). Krosno: Państwowa Wyższa Szkoła Zawodowa w Krośnie.

14. Klarin, M., Pororoković, A., Sacic, S.S., Arnaudova, V. (2012). Some characteristics of social interactions among adolescents in Croatia, Bosnia and Herzegovina, and Macedonia. J Psychol Res Behav Manag, 5, 163-172. https://doi.org/10.2147/prbm.s36389 
15. Kościuczuk, J., Krajewska-Kułak, E., Okurowska-Zawada, B. (2016). Aktywność fizyczna studentów fizjoterapii i dietetyki, Medycyna Ogólna i Nauki o Zdrowiu, 22(1), 51-58. https://doi. org/10.5604/20834543.1198724

16. Łaszek, M., Nowacka, E., Gawron-Skarbek, A., Szatko, F. (2011). Negative behavior patterns of students. Part II. Physical activity and eating habits. Probl Hig Epidemiol, 92(3), 461- 465.

17. Markiewicz-Górka, I., Korneluk, J., Pirogowicz, I. (2011). Aktywność fizyczna oraz wiedza studentów Akademii Medycznej we Wrocławiu na temat jej roli w profilaktyce chorób - badania ankietowe. Family Medicine \& Primary Care Review, 13, 436-439.

18. Ministerstwo Sportu i Turystyki (2015). Badanie poziomu aktywności fizycznej społeczeństwa w 2015 r. - analiza wyników. Pobrane z: http://www.msport.gov.pl/badania-i-analizy/aktywnosc-fizyczna -spoleczenstwa

19. Mynarski, W., Rozpara, M., Królikowska, B., Puciato, D., Graczykowska, B. (2012). Jakościowe i ilościowe aspekty aktywności fizycznej. Opole: Politechnika Opolska.

20. Novak, D., Doubova, S.V., Kawachi, I. (2016). Social capital and physical activity among Croatian high school students. Public Health, 135, 48-55. http://dx.doi.org/10.1016/j.puhe.2016.02.002

21. Prusik, K., Zaporozhanov, V., Görner, K. (2009). Stan aktywności fizycznej w stylu życia studentów Akademii Wychowania Fizycznego i Sportu w Gdańsku. Problemy Wychowania Fizycznego i Sportu, 12, 229233.

22. Rothon, C., Goodwin, L. (2012). Family social support, community «social capital» and adolescents' mental health and educational outcomes: a longitudinal study in England. Soc Psychiatry Psychiatr Epidemiol, 47, 697-709. https://doi.org/10.1007/s00127-011-0391-7

23. Soguksu, K. (2011). Physical activity level between Polish and Turkish university students (IPAQ). In: B. Bergier (Ed.), Physical activity in health and disease (s.19-28). Biała Podlaska: Pope Paul II State School of Higer Education in Biała Podlaska.

24. Sokołowski, M., Bronowicki, S., Kaiser, A. (2008). Nowoczesne formy aktywności fizycznej, W: E. Szczepanowska, M. Sokołowski (red.), Aktywność fizyczna i odżywianie się jako uwarunkowania promocji zdrowia (s.257-270). Poznań: Wielkopolska Wyższa Szkoła Turystyki i Zarządzania.

25. Stępień, E., Bergier, B., Niźnikowska, E., Bergier, J. (2015). Selected factors differentiating the forms of physical activity taken up or expected by the students of PSW in Biała Podlaska. Central European Journal of Sport Sciences and Medicine, 10 (2), 87-94.

26. Wang, Z., Byrne, N.M., Kenardy, J.A., Hills, A. (2005). Influences of ethnicity and socio-economic status on the body dissatisfaction and eating behaviour of Australian children and adolescents. Eat Behav. 6, 23-33. https://doi.org/10.1016/j.eatbeh.2004.05.001

27. Wojciechowski, L., Bergier, M. (2016). Physical activity of the Biała Podlaska prison staff and its conditioning factors, Health Problems of Civilization, 10(3), 47-56 https://doi.org/10.5114/hpc.2016.61366

28. Zaleski, R, Niewęgłowski, T. (2006). Aktywność ruchowa studentów Trójmiasta zdeterminowana płcią. Ann UMCS Sect D,. 60(Suppl. 16), 424-427. 